\title{
JALUR PENINGKATAN MUTU MADRASAH DI JAWA TENGAH: PROBLEM DAN SOLUSI
}

Oleh Aji Sofanudin

\section{Daftar Isi}

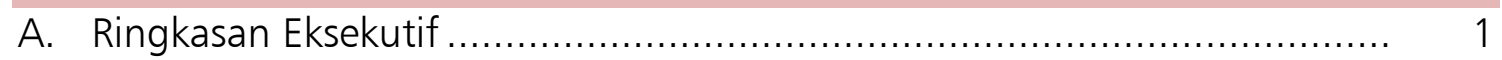

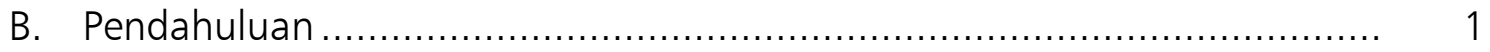

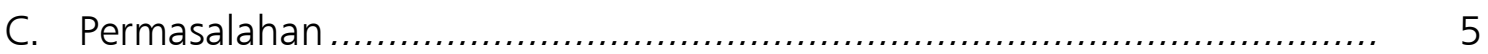

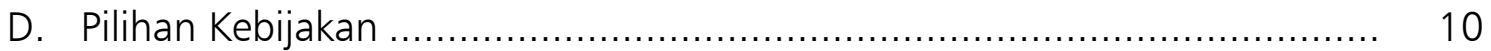

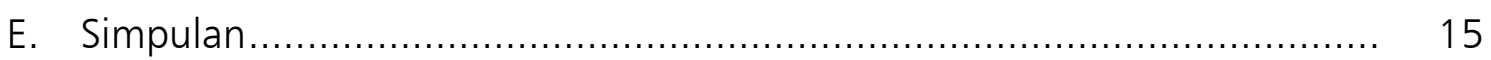

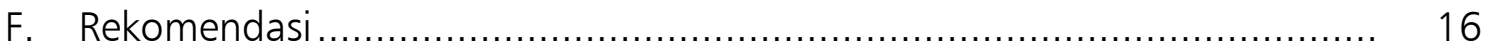

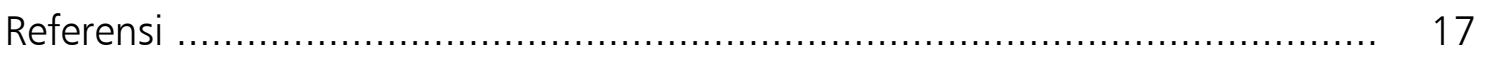




\section{A. RINGKASAN EKSEKUTIF}

Upaya peningkatkan mutu madrasah telah dilakukan dengan berbagai cara. Salah satunya dilakukan oleh Direktorat KSKK, yakni merumuskan tagline madrasah mandiri berprestasi (2021). Semua program dan kegiatan tersebut diarahkan dalam kerangka peningkatan mutu madrasah. Mutu madrasah menyangkut dua hal: mutu standar dan mutu persepsi. Dalam konteks madrasah/sekolah, mutu standar menyangkut akreditasi lembaga. Madrasah bermutu adalah madrasah yang memiliki nilai akreditasi tinggi. Sementara mutu persepsi menyangkut animo masyarakat terhadap madrasah. Mutu persepsi ditunjukkan dengan adanya seleksi dalam penerimaan siswa baru dan jumlah murid yang banyak. Untuk memperolah dua mutu tersebut, tentu madrasah harus menunjukkan performa yang baik, pengelolaan yang baik, serta mampu menunjukkan berbagai prestasi. Beberapa problem umum yang dialami madrasah di Jawa Tengah menyangkut lima hal pokok: (1) Madrasah milik masyarakat, (2) Ekonomi menengah ke bawah, (3) Akreditasi madrasah, (4) Kualitas pembelajaran dan (5) Fungsi ganda madrasah. Alternatif solusi yang ditawarkan adalah (1) penegrian madrasah, (2) penguatan wakaf untuk pendidikan, (3) peningkatan akreditasi madrasah, (4) Penyebarluasan quality madrasah for all, serta (5) keseimbangan fungsi pendidikan dan dakwah. Peningkatan mutu madrasah bermuara pada peningkatan prestasi madrasah. Prestasi madrasah dapat tercapai dengan menghadirkan semangat juang (ruhul jihad) dari keluarga madrasah, khususnya kepala madasah dan guru. Selain motivasi akhirat melalui ruhul jihad, upaya peningkatan mutu madrasah dilakukan melalui jalur duniawi yakni peningkatan kualifikasi dan kompetensi guru dan kepala madrasah secara berkelanjutan.

\section{B. PENDAHULUAN}

\section{Latar Belakang}

Upaya peningkatan mutu madrasah dilakukan oleh banyak pihak. Setidaknya ada empat kelompok yang telah melakukan upaya tersebut yakni: Departemen Agama (baca: kementerian agama atau pemerintah), Muhammadiyah, NU, dan kelompok tarbiyah (Subhan, 2012). Dari keempat kelompok tersebut, pemerintah cq Kementerian Agama dirasakan memiliki pengaruh paling besar dalam upaya peningkatan mutu madrasah. Saat ini, Dirjen Pendidikan Islam cq Direktorat KSKK menjadi ujung tombak pemerintah dalam peningkatan mutu madrasah.

Direktorat KSKK telah menelurkan berbagai kebijakan, salah satunya dengan membuat slogan. Cara ini dianggap efektif untuk memberikan arah, tujuan dan semangat kepada keluarga besar madrasah. Beberapa slogan yang pernah muncul 
adalah: madrasah lebih baik, lebih baik madrasah (2014), madrasah hebat bermartabat (2018), madrasah hebat bermartabat kelas dunia (2020), serta madrasah mandiri berprestasi (2021).

Mafhum bahwa karakteristik madrasah beragam. Ada madrasah mandiri, madrasah kompleks (MI, MTs, dan MA), serta ada madrasah yang berbasis pesantren. Semua tipe madrasah mengemban tugas yang sama yakni memberikan teladan terbaik dalam pengelolaan pendidikan (Sofanudin \& Atmanto, 2020). Madrasah diharapkan memiliki keunggulan dalam ilmu agama sebagaimana pesantren sekaligus memiliki keunggulan dalam ilmu umum sebagaimana sekolah (Sofanudin, 2016a). Daya tarik madrasah sejatinya ada pada nilai pendidikan agama. Dibandingkan dengan sekolah, madrasah memberikan materi pendidikan agama (Islam) lebih banyak.

Dilihat dari sejarah, perkembangan madrasah merupakan tindak lanjut dari pesantren (Steenbrink, 1986). Dilihat dari ciri penambahan mata pelajaran agama, madasah menghadapi banyak kompetitor seperti: sekolah Islam terpadu (SIT) (Sofanudin, 2019b), sekolah dibawah ormas keagamaan (Sekolah Muhammadiyah dan LP Ma'arif) (Ibda \& Sofanudin, 2021), serta sekolah di bawah yayasan pesantren (Sofanudin, Prihastuty, \& Ibda, 2021). Ketiga model sekolah tersebut, secara umum memberikan tambahan materi pendidikan agama Islam. Kompetitor madrasah bertambah dengan hadirnya lembaga penddikan yang melabeli dirinya dengan kuttab. Belakangan ini berkembangan kuttab dengan beragam nama (Sofanudin, Fanani, \& Prihastuty, 2021). Madrasah juga menghadapi kompetitor sekolah alam, yang salah satu unggulannya adalah nilai agama yang diajarkan, yakni sekolah alam yang berbasis agama (Sofanudin, 2019a).

Ada berbagai upaya yang telah melakukan untuk meningkatkan animo masyarakat terhadap madrasah. Berbagai upaya telah dilakukan untuk meningkatkan minat masyarakat terhadap madrasah, diantaranya adalah (1) memiliki program unggulan, (2) berakhlak mulia, ketaatan beragama, (3) banyak lulusan siswa/outcome diterima di sekolah favourit, (4) memiliki prestasi akademik dan non akademik (Sofanudin, 2016c). Bahkan, madrasah telah menunjukkan best practice di berbagai tempat (Sofanudin \& Atmanto, 2020; Sofanudin, Atmanto, \& Prihastuty, 2021).

Berbagai upaya tersebut telah menunjukkan hasilnya. Berdasarkan data yang ditunjukkan oleh situs Education Management Information System (EMIS) Kementerian Agama Rl, jumlah lembaga madrasah (dari RA hingga MA) mengalami kenaikan dalam dua tahun terakhir. RA, MI, MTs, dan MA yang pada Tahun Ajaran (TA) 2019/2020 Semester ganjil secara berturut-turut adalah 29.842 (RA), 25.593 (MI), 18.176 (MTs), dan 8.807 (MA) berubah menjadi 30.098 (RA), 25.816 (MI), 18.346 (MTs), dan 9.131 (MA) di TA 2020/2021 semester genap. 
Demikian juga dengan jumlah peserta didik. Pada TA 2019/2020 semester ganjil, jumlah seluruh peserta didik dari RA hingga MA sebanyak 9.450.198 siswa, sedangkan pada semester ganjil TA 2020/2021 jumlah mereka naik menjadi 9.681.284 siswa (Muawanah, 2021).

Temuan penelitian Muawanah, dkk (2021) menunjukkan bahwa persepsi masyarakat terhadap layanan pendidikan madrasah Ibtidaiyah dan madrasah tsanawiyah di Jawa Tengah menunjukkan bahwa rerata skor sebesar 3,18 (baik). Dari lima dimensi layanan pendidikan, diperolah skor sebagai berikut: reliability (keandalan) sebesar 2,82 (baik), responsiveness (daya tanggap) sebesar 3,27 (sangat baik), assurance (jaminan) sebesar 3,38 (sangat baik), emphaty (empati) sebesar 3,30 (sabat baik) dan tangibles (bukti fisik) sebesar 3,12 (baik). Dari lima dimensi tersebut, reliability adalah dimensi dengan rerata skor terendah $(2,82=$ baik $)$ dan dimensi assurance adalah dimensi layanan pendidikan dengan rerata skor tertinggi $(3,38=$ sangat baik).

Selain problem kelembagaan, pendidikan agama juga mempunyai problem menyangkut keterpenuhan dan keterlayanan terutama untuk kelompok minoritas (Sofanudin, 2019c). Pendidikan agama juga mengemban tugas tambahan untuk mengembangkan pendidikan karakter (Sofanudin, 2015). Meskipun demikian, dengan melihat berbagai realitas sejatinya problem mendasar pendidikan madrasah secara umum adalah mutu. Secara umum, mutu madrasah negeri lebih baik daripada madrasah swasta. Mafhum bahwa mayoritas madrasah adalah swasta sementara mayoritas sekolah berstatus negeri. Oleh karena itu, mutu madrasah secara umum lebih rendah dibandingkan dengan mutu sekolah. Banyak madrasah yang tidak memiliki sarana gedung yang memadai, bahkan ada pula yang tidak memiliki kebutuhan dasar seperti air dan listrik.

Beberapa madrasah juga telah melakukan inovasi. Inovasi sederhana misalnya dengan menggabungkan kurikulum madrasah dengan madrasah diniyah formal. Ada integrasi pendidikan formal dengan nonformal (Sofanudin, 2018). Madrasah juga telah melakukan berbagai inovasi untuk meningkatkan mutu pendidikan (Sofanudin, 2016b; Sofanudin, 2016a). Inovasi yang dikembangkan bisa berbentuk top down, bottom up, maupun combination (Sofanudin, Rokhman, Wasino, \& Rusdarti, 2016).

\section{Tujuan}

Tulisan ini bertujuan untuk mengetahui upaya peningkatan mutu madrasah. Tagline madrasah mandiri berprestasi sebagaimana yang dikonsep oleh Direktorat KSKK 2021 perlu dioperasionalisasikan. Cara yang dilakukan adalah mendeskripsikan berbagai problem yang dimiliki oleh madrasah. Setelah itu dicoba dicarikan obat atau solusi atas masalah yang dihadapi oleh madrasah. 
Mewujudkan madrasah mandiri berprestasi merupakan ikhtiar peningkatan mutu madrasah. Terkait kemandirian ekonomi, secara umum madrasah built in dengan kemandirian. Perolehan prestasi madrasah tentu terkait dengan mutu madrasah. Semakin banyak prestasi yang diperoleh maka mutu madrasah akan meningkat. Mutu madrasah ini dibatasi mutu absolut dan mutu persepsi (pelanggan). Mutu absolut melekat pada nilai madrasah sementara mutu persepsi lebih didasarkan atas minat masyarakat terhadap suatu layanan.

Policy paper ini, ditunjukkan untuk memberikan alternatif atau rekomendasi kebijakan terkait dengan beragam problem umum yang dihadapi madrasah. Bagaimana sebaiknya madrasah memberikan layanan terbaik untuk para stakeholders. Bagaimana sebaiknya pemerintah melakukan pembinaan dan pengaturan terkait model peningkatan mutu pada madrasah dilihat dari layanan madrasah. Berbagai upaya yang telah dilakukan oleh madrasah dalam peningkatan mutu. Berbagai kebijakan juga sudah dibuat oleh pemerintah dalam peningkatan mutu madrasah.

Secara umum, realitas permasalahan yang dihadapi madrasah berkisar pada beberapa hal sebagai berikut: (1) status kelembagaan madrasah, (2) ekonomi orang tua/wali murid, (3) akreditasi madrasah, (4) kualitas pembelajaran, dan (5) fungsi ganda madrasah.

\section{Metode}

Penelitian ini dilakukan terhadap hasil-hasil penelitian terkait pengelolaan madrasah dengan cara library research. Fokus utama pada hasil penelitian Muawanah, dkk (2021) tentang Persepsi Masyarakat terhadap Layanan Pendidikan Madrasah di Jawa Tengah. Selain itu, dikumpulkan juga hasil-hasil penelitian terdahulu untuk kemudian diperas "problem-problem" di seputar dunia madrasah.

Riset yang dilakukan Muawanah, dkk (2021) dilakukan pada delapan kabupaten/kota di Jawa Tengah di beberapa MI dan MTs. Sasaran madrasah yang menjadi lokus penelitian dengan mempertimbangkan tiga kategori: (1) kategori tinggi: Kab. Magelang dan Kab. Brebes, (2) kategori sedang: Kab. Banyumas, Kab. Tegal, dan Kab Semarang, (3) kategori rendah: Kab Sukoharjo, Kab Wonogiri, dan Kab Salatiga. Penelitian tersebut dilakukan dengan mix method, kualitatif dan kuantitatif. Pengumpulan data dilakukan dengan observasi, wawancara, telaah dokumen, dan angket sederhana. Analisis data dilakukan dengan deskriptif secara kualitatif dan kuantitatif.

Policy paper ini tidak terbatas mengacu pada hasil penelitian tersebut, tetapi merujuk pada temuan penelitian yang lain. Dari berbagai KTI tentang madrasah ditemukan lima problem mendasar yang dialami oleh sebagian besar madrasah yakni (1) status kelembagaan madrasah, (2) ekonomi orang tua/wali 
murid, (3) akreditasi madrasah, (4) kualitas pembelajaran, dan (5) fungsi ganda madrasah.

Para pengambil kebijakan perlu memahami karakteristik madrasah yang tidak sama persis dengan sekolah. Madasah menerima dan melaksanakan seluruh regulasi yang dibuat oleh Kemendibudristek ditambah menerima seluruh regulasi yang dibuat kementerian agama. Selain itu, madrasah (swasta) juga menanggung "beban" menerima dan melaksanakan seluurh kebijakan yang dibuat oleh yayasan penyelenggara (ormas, pesantren, yayasan pendidikan). Bisa jadi antara berbagai policy maker tersebut, tidak sama.

\section{Sistematika}

Policy paper ini disusun berdasarkan lima bagian: ringkasan eksekutif, pendahuluan, permasalahan, pilihan kebijakan, serta simpulan dan rekomendasi. Pertama, ringkasan eksekutif berisi ringkasan dari paper ini. Kedua, pendahuluan mengulas latar belakang fenomena pengelolaan madrasah, tujuan, metode dan sistematika. Ketiga, permasalahan mengungkapkan permasalahan umum yang dihadapi kebanyakan madrasah. Keempat, pilihan kebijakan berisi alternatif kebijakan dalam kerangka menyelesaikan masalah yang dialami madrasah. Bagian kelima adalah simpulan dan rekomendasi.

\section{PERMASALAHAN}

Permasalahan umum yang dihadapi madrasah dalam pengelolaan madrasah meliputi: (1) milik masyarakat atau berstatus swasta, (2) kondisi ekonomi orang tua, (3) akreditasi, (4) kualitas pembelajaran, dan (5) fungsi ganda madrasah.

\section{Madrasah adalah Milik Masyarakat}

Data emis Kementerian Agama RI menyebutkan bahwa mayoritas madrasah adalah milik masyarakat. Secara nasional, dari jumlah 83.391 madrasah (RA, MI, MTs, dan MA), sebanyak 79.336 berstatus swasta. Artinya Sebagian besar madrasah adalah milik masyarakat, sementara hanya 4.052 milik pemerintah. Madrasah negeri sebesar 4,86 \%, sementara madrasah swasta sebesar 95,14\%. Realitas ini berbeda dengan sekolah dimana mayoritas berstatus negeri.

Data kelembagaan madrasah dapat dilihat dari tabel berikut ini 
Tabel 1 Jumlah Lembaga Madrasah

\begin{tabular}{llccc}
\hline No & Lembaga & Negeri & Swasta & Jumlah \\
\hline 1 & Raudlatul Athfal & 0 & 30.098 & 30.098 \\
\hline 2 & Madrasah Ibtidaiyah & 1.713 & 24.103 & 25.816 \\
\hline 3 & Madrasah Tsanawiyah & 1.527 & 16.816 & 18.346 \\
\hline 4 & Madrasah Aliyah & 812 & 8.319 & 9.131 \\
\hline \multirow{2}{*}{ Jumlah } & 4.052 & 79.336 & 83.391 \\
\hline & Persentase & $4,86 \%$ & $95,14 \%$ & $100 \%$ \\
\hline
\end{tabular}

Sumber: Emis Dashboard, semester genap 2020/2021

Kendala umum yang dihadapi madrasah swasta cukup kompleks. Pada umumnya kebutuhan dasar madrasah yang belum terpenuhi, gedung madrasah yang minimalis, jumlah siswa minim, gaji guru, bahkan problem mendasar lainnya seperti ketersediaan listrik. Problem mendasar ini, pada umumnya dialami oleh madrasah-madrasah yang ada di perbatasan. Dunia madrasah bertalian erat dengan dunia kemiskinan dan keterbelakangan.

Keberadaan madrasah swasta yang demikian tentu tidak seluruhnya dialami oleh seluruh madrasah. Beberapa madrasah telah muncul dengan tawaran program unggulan. Beberapa madrasah telah mematok harga yang tinggi. Meskipun demikian, pada segmen masyarakat tertentu, semakin mahal madrasah justru semakin diminati oleh masyarakat. Animo masyarakat terhadap madrasah tersebut tinggi. Harga terkadang tidak menjadi masalah, yang penting mutu.

Madrasah yang berada di lingkungan pesantren juga memiliki karakteristik yang tidak sama dengan madrasah mandiri. Secara umum, ada integrasi pembelajaran antara madrasah dengan pesantren (Sofanudin, 2016a). Di lain sisi, ada juga madrasah negeri. Pada madrasah negeri, secara umum pengelolaan sama mengikuti seluruh ketentuan peraturan.

Di samping itu, ada juga MAN IC, yang berbeda secara pengelolaan dengan madrasah negeri pada umumnya. MAN IC dikelola secara langsung oleh Direktorat Pendidikan Islam. MAN IC secara umum mirip dengan madrasah yang berada di bawah pesantren. Namun, titik tekan IC lebih pada penguasaan sains dan teknologi, bukan pada penguasaan kitab kuning. Dilihat dari sejarahnya, keberadaan MAN IC adalah kelanjutan sejarah dari SMA Insan Cendekia yang digagas oleh BJ Habibie Ketika menjabat sebagai Menristek/Kepala BPPPT. Sekolah ini awalnya dibawah pengelolaan BPPT, tetapi kemudian diserahkan kepada Kementerian Agama dan berubah nama menjadi MAN IC. 
Dari sisi sejarah, madrasah negeri berasal dari dua kemungkinan, yakni pendirian baru atau penegrian dari madrasah swasta. Karakteristik madrasah negeri yang berasal dari swasta memiliki kultur madrasah swasta meskipun secara kelembagaan negeri. Tata Kelola madrasah ini, tentu perlu menyesuaikan dengan kebutuhan/mempertimbangan kebutuhan lokal. Pengelolaan madrasah memerlukan strategi khusus, karena kebanyakan madrasah adalah swasta.

Pemerintah sebagai pihak penyelenggara madrasah berbeda dengan mengurusi madrasah. Hubungan pemerintah dengan madrasah lebih bersifat kolaboratif, bukan instruktif antara atasan dan bawahan. Hubungan pemerintah dan madrasah adalah hubungan antara pemerintah dan masyarakat. Terlebih jika penyelenggara madrasah adalah pesantren, maka relasi yang dibangun adalah relasi dengan tokoh agama dan tokoh masyarakat.

Mafhum juga bahwa, yayasan penyelenggara madrasah juga beragam. Ada banyak corak pemikiran pengelola yayasan, ada yayasan yang berbasis organisasi masyarakat, ada yang berbasis yayasan lokal, bahkan ada yayasan yang tidak paham terkait pengelolaan madrasah.

Problem umum madrasah adalah perihal orientasi dan kesediaan SDM. Orientasi madrasah akan bervariasi sesuai dengan variasi penyelenggara pendidikan madrasah. Oleh karena itu, model pengelolaan madrasah akan efektif jika menggunakan model bottom up, dari bawah. Sesuai dengan kondisi madrasah masing-masing. Pemerintah tidak bisa melakukan intervensi, jika sudah menyangkut kebijakan. Cara mengelola madrasah negeri dengan madrasah swasta tentu berbeda. Pendekatan instruktif dan top down perlu dikurangi. Perlu dibangun pendekatan kolabosi dan sinergi serta pendekatan dakwah.

Pemerintah bisa ikut andil bagian terutama kepada guru/kepala madrasah yang berstatus negeri. Tidak melalui kelembagaan secara penuh, tetapi melalui personal guru yang bersangkutan. Pemrintah juga melalui program dan kegiatan seperti BOS (bantuan operasional madrasah) dan sertifikasi guru untuk mendongkrak mutu madrasah. Ada prasyarat tertentu yang harus dipenuhi oleh madrasah untuk memperoleh BOS, sertifikasi dan program lainnya dari pemerintah.

\section{Ekonomi Menengah ke Bawah}

Secara umum lokasi madrasah berada di pedesaan. Madrasah tumbuh subur di pedesaan bersamaan dengan semangat dakwah untuk para petani. Desa juga berkorelasi langsung dengan kemiskinan. Keberadaan madrasah lekat dengan kemiskinan masyarakat. Semangat madrasah adalah membantu pendidikan kelompok masyarakat yang kurang beruntung. 
Madrasah adalah lembaga pendidikan untuk semua, education for all. Sebagian besar orang tua/wali murid madrasah dilihat dari status sosial berlatar ekonomi menengah ke bawah. Artinya, kebanyakan secara sosial ekonomi pada umumnya berada pada kondisi ekonomi ke bawah.

Secara umum, orang tua wali yang memasukkan putra putrinya ke madrasah adalah kelompok santri. Santri adalah kelompok dalam masyarakat yang taat menjalankan agama. Clifford Geertz, dalam agama Jawa memasukkan santri sebagai komunitas yang taat menjalankan ajaran agama.

Munculnya new santri, kelas menengah santri mendorong berkembang madrasah kelas atas. Madrasah menjadi lembaga pendidikan untuk masyarakat kelas menengah atas. Madrasah tidak hanya diminati oleh masyarakat desa, masyarakat menengah ke bawah, dan pinggiran, tetapi diminati pula oleh masyarakat kota, masyarakat dan menengah ke atas.

Munculnya kelas sosial menengah, memungkinkan orang tua wali madrasah berubah menjadi orang tua wali murid. Sejalan dengan ini, memang memunculkan beberapa madrasah unggulan atau madrasah untuk kelas menengah. Beberapa madrasah saat ini, berbiaya mahal. Meskipun demikian, animo masyarakat terhadap madrasah kelas menengah cukup tinggi.

Madrasah juga identik dengan ormas keagamaan tertentu yakni Nahdlatul Ulama. Meskipun demikian, eksistensi madrasah ada juga pada ormas keagamaan yang lain seperti Muhammadiyah, Nahdlatul Wathon, Persis, dan lain sebagainya.

\section{Akreditasi Madrasah}

Ukuran mutu satuan pendidikan, termasuk madrasah adalah akreditasi. Sallis memberikan dua macam ukuran mutu: mutu absolut dan mutu subjektif. Dalam konteks madrasah, ukuran formal adalah akreditasi. Secara umum, madrasah yang memiliki akreditasi $A$ lebih baik daripada madrasah yang memiliki akreditasi B, dan seterusnya.

Akreditasi madrasah secara umum menggambarkan kualitas pendidikan. Delapan standar nasional Pendidikan (SNP) di-breakdown dalam angket/borang yang harus diisi oleh madrasah. Meskipun akreditasi madrasah dari tahun ke tahun mengalami peningkatan, namun secara faktual masih banyak madrasah yagn perlu ditingkatkan akreditasinya.

Berikut ini data madrasah berdasarkan akreditasi 
Tabel 2 Data Akreditasi Madrasah

\begin{tabular}{llrrrrr}
\hline No & Jenjang & $\begin{array}{c}\text { Jumlah } \\
\text { Madrasah }\end{array}$ & Akreditasi A & Akreditasi B & Akreditasi C & \multicolumn{1}{c}{ Belum } \\
\hline 1 & RA & 4.746 & 57 & 332 & 47 & 4,310 \\
\hline 2 & MI & 4.162 & 1.323 & 2.543 & 233 & 63 \\
\hline 3 & MTs & 1.757 & 515 & 998 & 194 & 50 \\
\hline 4 & MA & 722 & 155 & 368 & 158 & 41 \\
\hline & Jumlah & 11.387 & 2.050 & 4.241 & 632 & 4.464
\end{tabular}

Sumber: Kanwil Kementerian Agama Provinsi Jawa Tengah, 2021

Berdasarkan data, masih banyak madrasah yang belum terakreditasi, terutama pada RA. Secara umum persentase madrasah terakreditasi A dan B lebih banyak daripada madrasah terakreditasi $C$ dan belum terakreditasi. Dari tahun ke tahun semakin meningkat. Secara total 44, $75 \%$ madrasah kurang baik (akreditasi C dan D), sementara 55,25\% memiliki kualitas akreditasi yang bagus (akreditasi A dan B). hal ini tentu meningkat dibandingkan tahun-tahun sebelumnya.

Persentase madrasah swasta yang belum terakreditasi sekitar $20 \%$ yakni MIS $=16 \%$, MTs S $=21 \%$ dan MAS $=22 \%$. Sementara persentase madrasah yang memperoleh akreditasi A sekitar $15 \%$ yaitu MIS $=15 \%$, MTs $=15 \%$ dan MAS $=11 \%$ (Sofanudin, 2016). Jika madrasah yang memperoleh akreditasi A dan B dianggap sebagai madrasah yang baik serta madrasah yang memperoleh akreditasi $C$ atau belum terakreditasi adalah madrasah yang tidak baik. Maka gambaran "madrasah baik" lebih tinggi daripada "madrasah tidak baik". Meskipun demikian, madrasah tidak baik persentasenya cukup tinggi. Pada madrasah swasta, persentase madrasah tidak baik sekitar $40 \%$ (MIS $=34 \%$, MTs S $=42 \%$ dan MA S $=47 \%$ ).

\section{Kualitas Pembelajaran}

Zamroni (2013) menyebutkan mutu pendidikan menyangkut dua hal yaitu mutu proses pembelajaran dan mutu hasil belajar. Temuan Saimroh, dkk (2021) menyebutkan bahwa kualitas pembelajaran belum memenuhi target yang ditentukan. Terdapat gap yang cukup lebar antara target dan capaian nilai UN pada tahun 2019. Selain itu, capaian UN untuk jenjang MTs/SMPTK dan MA/SMATK/SMAK selama lima tahun (2015-2019 cenderung mengalami penurunan setiap tahunnya.

Kualitas pembelajaran di madrasah terkait erat dengan kualitas guru. Kualitas guru dipacu salah satunya dengan sertifikasi. Sertifikasi merupakan pemberian sertifikat pendidik kepada guru untuk memberikan nilai kompetensi dan kelayakan seorang guru dalam proses belajar mengajar. Data emis 2021 
menyebutkan bahwa secara nasional jumlah total guru madrasah adalah 771.318 orang. Dari jumlah tersebut sebanyak 313.068 (40,58 \%) sudah tersertifikasi, dan sebanyak $458.250(59,42 \%)$ belum tersertifikasi. Jika sertifikasi dijadikan ukuran maka sekitar $60 \%$ guru madrasah belum berkualitas.

Tahun 2020 - 2024, kualitas pembelajaran dalam renstra Kementerian Agama akan menggunakan skor tes AKM (Asesmen Kompetensi Minimal) dan skor PISA (Program for International Student Assessment).

\section{Fungsi Ganda Madrasah}

Madrasah memiliki karakteristik yang berbeda dengan sekolah. Meskipun UU Nomor 20 Tahun 2003 tentang Sistem Pendidikan Nasional tidak membedakan antara sekolah dan madrasah, dalam praktikya madrasah memegang dua peran ganda. yakni fungsi pendidikan dan fungsi dakwah. Madrasah adalah lembaga pendidikan (sains) di satu sisi, dan lembaga dakwah (pewarisa nilai) di sisi yang lain.

Motivasi pendirian madrasah lebih banyak karena dorongan dakwah, yakni dakwah melalui pendidikan. Madrasah menjadi sarana berdakwah para keluarga besar madrasah. Para orang tua, memasukkan putra-putri mereka ke madrasah didorong oleh motivasi belajar agama.

Fungsi ganda madrasah, sedikit banyak akan berpengaruh terhadap pengelolaan madrasah berbasis kekeluargaan. Di banyak lembaga ditemukan yayasan, kepala, guru, dan TU adalah memiliki hubungan kekerabatan. Dengan model pengelolaan seperti ini, akan menyulitkan untuk menerapkan reward and punishment dalam manajemen. Dengan mengemban fungsi dakwah, maka "seleksi" untuk peningkatan mutu, tidak diutamakan. "Orang mau mengaji koq dilarang".

Madrasah merupakan lembaga berbasis masyarakat, dari masyarakat oleh masyarakat dan untuk masyarakat. Berbagai ormas keagamaan, pada umumnya akan mendirikan madrasah sebagai salah satu amal usaha. Model pengelolaan madrasah aka berbasis keluarga dan jaringan kekerabatan (dzuriyat).

Model ini tidak sepenuhnya jelek, bisa juga mendatangkan efektivitas dan efisiensi pengelolaan. Pada umumnya, para pendiri madrasah memiliki motivasi dakwah, motivasi amal jariyah. Sehingga tidak memikirkan "keuntungan" dalam pengleolaannya. Justru, para pengelola madrasah mengeluarkan tenaga, biaya, dan berjuang untuk memajukan madrasah.

Karakteristik madrasah berbeda dengan sekolah. Ada nilai "ikhlas beramal" dalam model pengelolaan madrasah. Motivasi ini yang kerap kali alpa dilihat oleh para pengambil kebijakan. 


\section{PILIHAN KEBIJAKAN}

\section{Kebijakan yang Ada}

Dalam menyelesaikan berbagai problem madrasah tersebut perlu dicari dan dikembangkan beberapa alternatif solusi:

\section{Penegrian Madrasah}

Upaya peningkatan mutu madrasah melalui penegrian madrasah merupakan salah satu opsi. Meskipun disadari bahwa tidak semua madrasah swasta mau dinegerikan. Upaya peningkatan mutu madrasah melalui penegerian jarang dilakukan oleh pemerintah. Bahka perkembangan MIN pernah bersifat stagnan. Selama lima tahun jumlah MIN tetap dan tidak berubah (Sofanudin, 2016). Ini artinya Kementerian Agama tidak melakukan upaya peningkatan mutu madrasah melalui proses penegrian madrasah ibtidaiyah.

Penegrian madrasah dapat dilakukan untuk meningkatkan mutu madrasah. Dengan cara ini akan efektif terutama terhadap beberapa madrasah yang dikelola yayasan. Dengan penegrian sumber daya madrasah akan lebih mudah terpenuhi: tenaga pendidik dan kependidikan, gedung, dan sarana prasarana pendidikan lainnya.

Peningkatan mutu madrasah bisa dilakukan dengan cara penegrian terhadap madrasah-madrasah swasta, terutama yang berada di pinggiran. Madrasah memang mengembangkan tugas education for all, perlu didorong untuk bergeser menjadi quality education for all. Kewajiban pemerintah untuk meningkatkan mutu madrasah, yaitu mutu proses dan hasil belajar siswa.

Penegrian madrasah dapat dilakukan dengan menggandeng pemerintah daerah. Meskipun kementerian Agama merupakan instansi vertical, tidak salah juga dibuat regulasi yang memungkinkan kepala daerah (Gubernur, Bupati/Walikota) untuk berpartisipasi dalam memajukan Pendidikan agama. Salah satunya melalui proses penegrian terhadap madrasah. Perlu dibuat terobosan regulasi, yang memungkinkan kepala daerah berkontribusi dalam proses peningkatan mutu madrasah.

\section{Penguatan Wakaf Produktif untuk Pendidikan}

Madrasah adalah milik masyarakat, oleh karena itu peningkatan mutu madrasah juga harus melibatkan masyarakat. Salah satu upaya yang bisa dilakukan misalnya dengan menggiatkan wakaf produtif. Perlu upaya massif untuk mengembangkan adanya wakaf untuk pendidikan.

Partisipasi masyarakat terhadap madrasah merupakan sebuah keharusan, karena memang madrasah milik masyarakat. Salah satu upaya yang dilakukan 
adalah dengan meningkatkan partisipasi masyarakat. Madrasah perlu mengajak para aghniya untuk berpartisipasi aktif untuk mengembangkan madrasah.

Bentuk partisipasi lain dapat dilakukan dengan mengadakan kegiatankegiatan kemasyarakatan: sholat berjamaah di masjid/musholla, bersih-bersih tempat ibadah (masjid/musalla), membersihkan makam, aktif di PHBI (peringatan hari besar Islam) yang melibatkan masyarakat, Idul Adha, dan kegiatan kemasyarakatan lainnya.

\section{Peningkatan Akreditasi Madrasah}

Meskipun disadari betul bahwa akreditasi tidak serta merta menjamin mutu madrasah, namun disadari bahwa ukuran formal mutu madrasah adalah akreditasi. Madrasah perlu mengembangkan sebuah system untuk mendukung peningkatan akreditasi madrasah.

Salah satu upaya yang bisa dilakukan misalnya dengan membuat inovasi struktur organisasi madrasah. Misalnya ada PJ Akreditasi atau bidang yang mengurusi data sehingga ketika dibutuhkan/visitasi akreditasi akan lebih mudah dilakukan. Best practice pengelolaan madrasah untuk peningkatan akreditasi perlu dilakukan. Para stakeholder perlu memikirkan alternatif solusi tersebut.

Dalam implementasi akreditasi madrasah terkadang juga tidak bisa menggambarkan secara detail kualitas madrasah. Ada deviasi dalam pelaksanaan penentuan akreditasi madrasah (visitasi). Oleh karena itu, perlu juga dikembangkan Evaluasi Diri Madrasah (EDM) sebagai alat bercermin bagi madrasah untuk melangkah ke depan yang lebih baik lagi.

Peningkatan akreditasi madrasah dapat berjalan seiring peningkatan prestasi madrasah. Direktur KSKK telah mem-breakdown prestasi dengan beberapa dimensi/aspek: (1) prestasi dalam belajar, (2) prestasi dalam hidup, (3) prestasi dalam berkarya, (4) prestasi dalam berinovasi, (5) prestasi akademik/non akademik, (6) prestasi dalam afektif/karakter, (7) prestasi dalam skil//keterampilan, (8) prestasi dalam kompetisi dalam kebaikan (fastabiqul khairot) (Isom, Power Point 2021)

\section{Penyebarluasan Quality Madrasah for All}

Madrasah perlu membuat branding bahwa madrasah cocok untuk semua kalangan. Quality madrasah for all, madrasah berkualitas untuk semua. Tidak hanya masyarakat desa, masyarakat kelas menengah ke bawah, dan petani/nelayan. Madrasah juga cocok untuk masyarakat perkotaan dan menengah ke atas.

Madrasah perlu menghadirkan wajah untuk semua: desa kota, miskin kaya. Madrasah perlu menghadirkan wajah Islam moderat, Islam rahmatan lil alamin. Treatment terhadap madrasah perlu disesuaikan dengan kondisi faktual masing- 
masing madrasah. Virus peningkatan mutu madrasah perlu terus digaungkan dalam kepada semua jenis madrasah.

\section{Keseimbangan Fungsi Pendidikan dan Dakwah}

Madrasah memiliki dua fungsi yakni pendidikan dan dakwah. Oleh karena itu, perlu diperlukan adanya keseimbangan dalam mengemban kedu afungsi tersebut. Menghilangkan salah satu fungsi tersebut, sama dengan mematikan madrasah itu sendiri. Ibarat mata uang, fungsi Pendidikan dan dakwah adalah dua sisi dalam satu kesatuan. Tidak bisa dipisahkan, tetapi bisa dibedakan.

Menonjolkan fungsi dakwah dalam madrasah akan menjadikan fungsi pendidikan berkurang. Akibatnya mutu pendidikan menjadi taruhan. Oleh karena itu, pendidikan yang mengedepankan profesionalisme pengelolaan Pendidikan harus terus diutamakan. Tentu tanpa menghilangkan peran dakwah. Peran Pendidikan diperbesar dengan menunjukkan prestasi madrasah di berbagai bidang, baik akademik maupun non akademik.

Meskipun demikian, keluarga besar madrasah perlu berbangga hati karena ada trend peningkatan jumlah lembaga dan siswa pada madrasah. Berikut ini adalah data yang diolah dari tahun 2011 s.d 2021.

Tabel 3 Perkembangan Jumlah Lembaga

\begin{tabular}{ccccrrr}
\hline NO & $\begin{array}{c}\text { TAHUN } \\
\text { AJARAN }\end{array}$ & RA & MI & MTS & MA & $\begin{array}{c}\text { JUMLAH } \\
\text { TOTAL }\end{array}$ \\
\hline 1 & $2010 / 2011$ & 24318 & 22468 & 14757 & 6415 & 67958 \\
\hline 2 & $2011 / 2012$ & 24988 & 22344 & 15239 & 6768 & 69339 \\
\hline 3 & $2012 / 2013$ & 27334 & 23939 & 15594 & 6919 & 73786 \\
\hline 4 & $2013 / 2014$ & 27978 & 23678 & 16283 & 7260 & 75199 \\
\hline 5 & $2014 / 2015$ & 27875 & 24353 & 16741 & 7582 & 76551 \\
\hline 6 & $2015 / 2016$ & 27999 & 24560 & 16934 & 7843 & 77336 \\
\hline 7 & $2016 / 2017^{*}$ & 0 & 0 & 0 & 0 & \\
\hline 8 & $2017 / 2018^{*}$ & 0 & 0 & 0 & 0 & \\
\hline 9 & $2018 / 2019$ & 29842 & 25593 & 18176 & 8807 & 82418 \\
\hline 10 & $2019 / 2020$ & 29842 & 25593 & 18176 & 8807 & 82418 \\
\hline 11 & $2020 / 2021$ & 30104 & 25816 & 18351 & 9131 & 83402 \\
\hline
\end{tabular}

Sumber: Muawanah, dkk 2021 
Tabel 4 Perkembangan Jumlah Siswa

\begin{tabular}{rlrrrrr}
\hline NO & $\begin{array}{l}\text { TAHUN } \\
\text { AJARAN }\end{array}$ & \multicolumn{1}{l}{ RA } & MI & MTS & MA & $\begin{array}{c}\text { JUMLAH } \\
\text { TOTAL }\end{array}$ \\
\hline 1 & $2010 / 2011$ & 998658 & 3082226 & 2587106 & 1001998 & 7669988 \\
\hline 2 & $2011 / 2012$ & 975221 & 2874601 & 353508 & 899222 & 5102552 \\
\hline 3 & $2012 / 2013$ & 1115222 & 3269771 & 2781647 & 1064148 & 8230788 \\
\hline 4 & $2013 / 2014$ & 1174257 & 3290240 & 2817838 & 1099366 & 8381701 \\
\hline 5 & $2014 / 2015$ & 1180243 & 3463028 & 3158689 & 1208616 & 9010576 \\
\hline 6 & $2015 / 2016$ & 1231101 & 3565875 & 3160685 & 1294776 & 9252437 \\
\hline 7 & $2016 / 2017$ & 0 & 0 & 0 & 0 & \\
\hline 8 & $2017 / 2018$ & 0 & 0 & 0 & 0 & \\
\hline 9 & $2018 / 2019$ & 962.449 & 3925713 & 3096591 & 1465445 & 9450198 \\
\hline 10 & $2019 / 2020$ & 962449 & 3925713 & 3096591 & 1465445 & 9450198 \\
\hline 11 & $2020 / 2021$ & 1162417 & 3864586 & 3152486 & 1501795 & 9681284 \\
\hline
\end{tabular}

Sumber: Muawanah, dkk 2021

Tabel 3 dan 4 menjelaskan bahwa ada trend peningkatan jumlah lembaga dan jumlah siswa madrasah dari tahun 2011 s.d 2021. Artinya, animo masyarakat terhadap madrasah dari tahun ke tahun semakin meningkat. Di lain sisi, meskipun angka absolut sekolah lebih tinggi daripada madrasah, ada trend penurunan (jumlah sekolah dan jumlah siswa) selama lima tahun terakhir (2016 - 2021) yang terjadi di Jawa Tengah (Muawanah, 2021).

Dari uraian di atas berbagai problem madrasah dan alternatif dapat digambarkan sebagaimana bagan 1. Bagan 1 menjelaskan dua jalur peningkatan mutu madrasah, yakni jalur duniawi dan jalur ukhrawi. Pada prinsipnya semua stakeholders madrash berpengaruh terhadap peningkata mutu madrasah. Beberapa pihak yang memiliki andil dalam meningkatkan mutu madrasah diantaranya adalah pemerintah, ormas, Yayasan penyelenggara, komite, orang tua/wali, dan masyarakat sekitar. Namun, disadari betul bahwa ujung tombak peningkatan mutu madrasah sesungguhnya adalah kepala dan guru madrasah. Kepala dan guru madrasah perlu terus meniti dua jalur, yakni selalu meningkatkan kualifikasi dan kompetensi serta memiliki etos ruhul jihad, semangat juang atau niat yang ikhlas untuk berjuang melalui madrasah. Nilai "ikhlas beramal" sebagaimana tagline kementerian agama perlu diejawantahkan dalam kehidupan sehari-hari. 
Bagan 1 Dua Jalur Peningkatan Mutu Madrasah

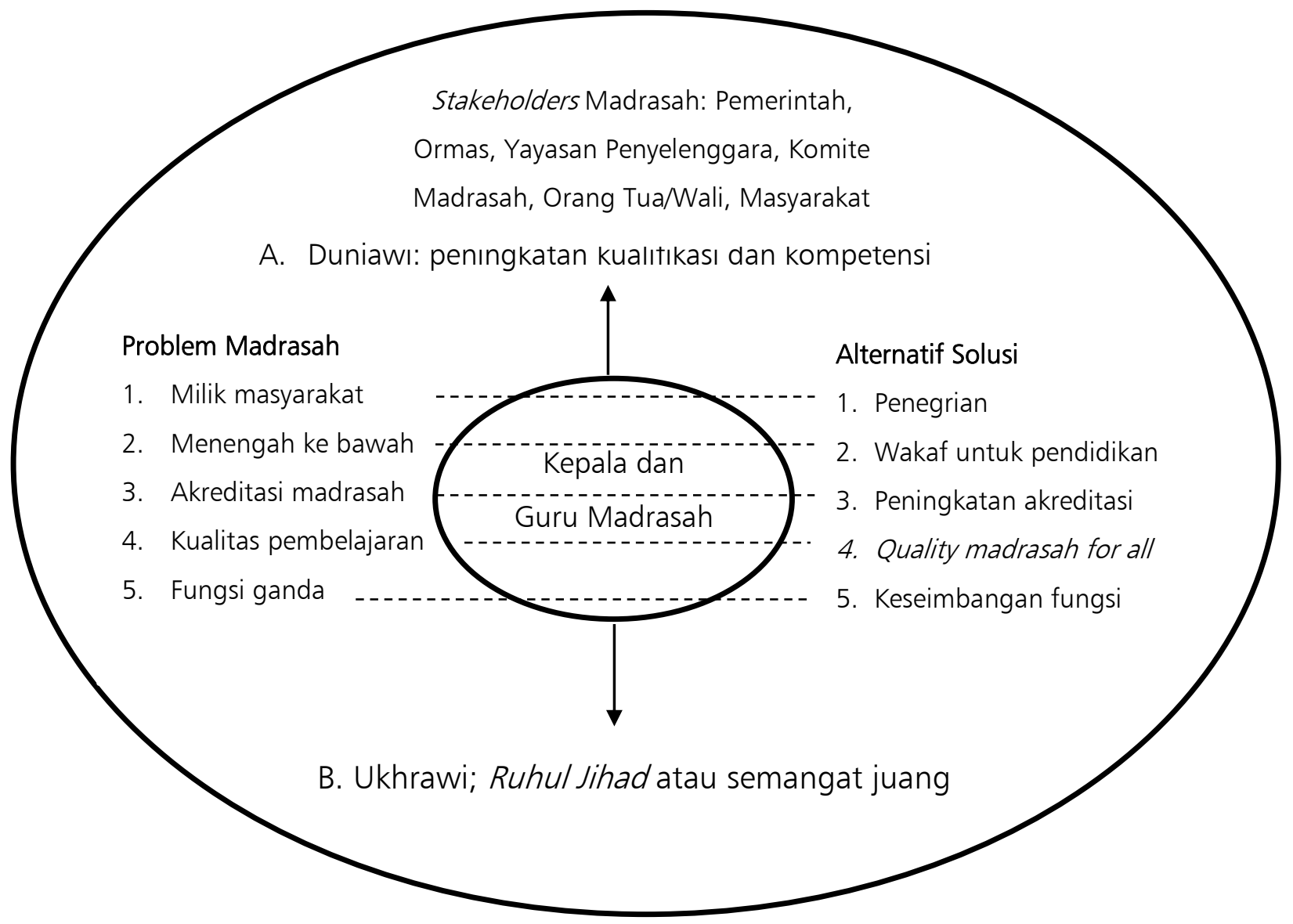

\section{SIMPULAN}

Keluarga besar madrasah perlu berbangga hati hati karena ada trend perkembangan madrasah meningkat. Di Jawa Tengah, meskipun angka absolut madrasah kalah dibandingkan dengan sekolah, tetapi perkembangan madrasah dari sisi lembaga maupun jumlah siswa terus meningkat. Ada trend peningkatan jumlah lembaga dan jumlah siswa lima tahun belakangan.

Tagline Direktur KSKK yang baru tahun 2021: madrasah mandiri dan berprestasi perlu digaungkan. Secara kuantitatif jumlahnya meningkat, namun secara kualitas masih perlu ditingkatkan. Model peningkatan mutu madrasah dapat dilakukan dengan ekplorasi kemampuan kepala madrasah dan guru mengelola madrasah. Teori barat tidak bisa menjelaskan pengembangan SDM pada guru. Internalisasi nilai "ikhlas beramal" harus terus diteladankan kepada keluarga besar madrasah, khususnya kepala madrasah dan guru. Jika ini dilakukan maka kemandirian dan prestasi madrasah bukan mustakhil dalam waktu yang tidak terlalu lama dapat tercipta. 
Beberapa indikator peningkatan mutu madrasah misalnya (1) adanya trend peningkatan animo masyarakat terhadap madrasah (peningkatan jumlah lembaga dan jumlah ssiwa), (2) Tumbuh suburnya madrasah yang dikelola secara modern, (3) Pengelolaan madrasah yang dilakukan dengan cara profesional, (4) kemampuan madrasah berkompetisi di berbagai ajang, baik nasional maupun internasional.

Upaya peningkatan mutu madrasah bermuara pada peningkatan mutu guru dan kepala madrasah. Peningkatan mutu guru dan kepala madrasah dilakukan dengan dua jalur: duniawi dan ukhrawi. Jalur duniawi yakni dengan peningkatan kualifikasi dan kompetensi tenaga pendidik dan kependidikan secara berkelanjutan. Jalur ukhrawi dilakukan dengan peningkatan motivasi jihad atau ruhul jihad yang perlu ditanamkan pada seluruh keluarga besar madrasah.

\section{REKOMENDASI}

Dari uraian di atas dan memperhatikan berbagai alternatif solusi di atas maka diharapkan peran policy maker atau pembuat kebijakan melakukan berbagai hal berikut ini:

1. Direktur Jenderal Pendidikan Islam cq Direktur Kurikulum, Sarana, Kesiswaaan dan Kelembagaan (KSKK) Madrasah Kementerian Agama RI perlu terus meningkatkan mutu madrasah seiring dengan adanya trend peningkatan jumlah madrasah (lembaga dan jumlah siswa) dari tahun ke tahun

2. Direktur Jenderal Pendidikan Islam cq Direktur KSKK Madrasah Kementerian Agama RI perlu mendorong peningkatan prestasi madrasah melalui keikutsertaan dalam berbagai ajang kompetisi di berbagai tingkatan

3. Direktur Jenderal Pendidikan Islam cq Direktur KSKK Madrasah Kementerian Agama RI perlu memberikan pengakuan kepada madrasah berpretasi di berbagai bidang misalnya: madasah akademik, madrasah program keagamaan, madrasah plus keterampilan, dan madrasah riset untuk semua jenjang pendidikan

4. Direktur Jenderal Pendidikan Islam cq Direktur Guru dan Tenaga Kependidikan (GTK) Kementerian Agama RI perlu membuat pemetaan kualitas kepala dan guru madrasah (assessment) untuk semua mata pelajaran 


\section{REFERENSI}

Ibda, H., \& Sofanudin, A. (2021). Program Gerakan Literasi Ma'arif dalam Meningkatkan Moderasi Beragama (Wasatiyyah Islam). Tatar Pasundan, Volume 15,

Muawanah, Siti, dkk. (2021). Persepsi Masyarakat terhadap Layanan Pendidikan Madrasah di Jawa Tengah. Semarang: Laporan Teknis Balai Litbang Agama Semarang, unpublished

Saimroh, Umi Muzayanah, Baso Maranu. (2021). Evaluasi Capaian Pendidikan Agama dan Keagamaan. Policy Paper

Sofanudin, A. (2015). Internalisasi nilai-nilai karakter bangsa melalui mata pelajaran pendidikan agama Islam pada SMA eks-RSBI di Tegal. Jurnal SMaRT, 1(2), 151-163.

Sofanudin, A. (2016a). Manajemen Inovasi Pendidikan Berorientasi Mutu Pada MI Wahid Hasyim Yogyakarta. Cendekia: Journal of Education and Society. https://doi.org/10.21154/cendekia.v14i2.820

Sofanudin, A. (2016b). Manajemen Inovasi Pendidikan Berorientasi Mutu Pada Min Malang 1 Kota Malang. Penamas.

Sofanudin, A. (2016c). MODEL PENINGKATAN MINAT MASYARAKAT TERHADAP MADRASAH IBTIDIYAH DI JAWA TENGAH. Nadwa. https://doi.org/10.21580/nw.2012.6.1.459

Sofanudin, A. (2018). Integrasi Pendidikan Formal dan Nonformal (Respon Satuan Pendidikan terhadap Kebijakan FDS). In et all Ahwan Fanani (Ed.), Kapita Selekta KF Doktor; Melintasi Tapal Batas Keilmuan (Pertama, pp. 1-26). Retrieved from https://www.researchgate.net/publication/340546388_Integrasi_Pendidikan _Formal_dan_Nonformal_Respon_Satuan_Pendidikan_terhadap_Kebijakan_ FDS\#fullTextFileContent

Sofanudin, A. (2019a). BEST PRACTICE IMPLEMENTASI KURIKULUM PADA SEKOLAH ALAM INSAN MULIA (SAIM) SURABAYA. Jurnal SMART (Studi Masyarakat, Religi, Dan Tradisi). https://doi.org/10.18784/smart.v5i1.744

Sofanudin, A. (2019b). CURRICULUM TYPOLOGY OF ISLAMIC RELIGION EDUCATION IN INTEGRATED ISLAMIC SCHOOL (SIT). EDUKASI: Jurnal Penelitian Pendidikan Agama Dan Keagamaan. https://doi.org/10.32729/edukasi.v17i1.563

Sofanudin, A. (2019c). Kebijakan Kementerian Agama dalam Pelayanan Pendidikan Agama Kelompok Minoritas. Penamas. 
Sofanudin, A., \& Atmanto, N. E. (2020). Penyebarluasan Best Practice Madrasah Ibtidiyah. Policy Brief Balai Litbang Agama Semarang.

Sofanudin, A., Atmanto, N. E., \& Prihastuty, R. (2021). Best Practice Pengelolaan Madrasah Ibtidaiyah Berbasis Pesantren Di Yogyakarta. Educandum, Volume 7.

Sofanudin, A., Fanani, A., \& Prihastuty, R. (2021). Islamic Education and Islamic Revivalism in Indonesia: A Case Study of Kuttab Al-Fatih Purwokerto. Analisa Journal of Social Science and Religion, Volume 6,

Sofanudin, A., Prihastuty, R., \& Ibda, H. (2021). Pola Asuh Peserta Didik pada Sekolah Menengah Islam Terpadu (SMIT) Bina Amal Semarang. Dialog, 44(1).

Sofanudin, A., Rokhman, F., Wasino, W., \& Rusdarti, R. (2016). Quality-Oriented Management of Educational Innovation at Madrasah Ibtidaiyah. Journal of Education and Practice.

Steenbrink, K. A. (1986). Pesantren Madrasah Sekolah; Pendidikan Islam dalam Kurun Moderen (Pertama). Jakarta: Lembaga Penelitian, Pendidikan dan Penerangan Ekonomi dan Sosial.

Subhan, A. (2012). Lembaga Pendidikan Islam di Indonesia Abad ke-20, Pergumulan antara Modernisasi dan Identitas. Jakarta: Kencana.

Zamroni. (2013). Manajemen Pendidikan Suatu Usaha Meningkatkan Mutu Sekolah. Yogyakarta: Ombak.

http://emispendis.kemenag.go.id/dashboard/?smt=20202 